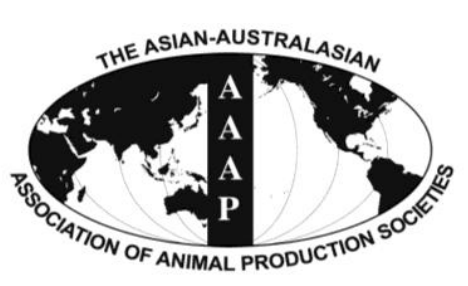

Open Access

Asian Australas. J. Anim. Sci.

Vol. 27, No. 11 : 1571-1576 November 2014

http://dx.doi.org/10.5713/ajas.2014.14204

www.ajas.info

pISSN 1011-2367 elSSN 1976-5517

\title{
Assessment of Anti-nutritive Activity of Tannins in Tea By-products Based on In vitro Rumen Fermentation
}

\author{
Makoto Kondo $^{1,2, *}$, Yoshiaki Hirano ${ }^{2,3}$, Noriyuki Ikai ${ }^{2}$, Kazumi Kita ${ }^{2,4}$, \\ Anuraga Jayanegara ${ }^{5}$, and Hiro-omi Yokota ${ }^{2}$ \\ ${ }^{1}$ Graduate School of Bioresources, Mie University, Mie, 514-8507, Japan
}

\begin{abstract}
Nutritive values of green and black tea by-products and anti-nutritive activity of their tannins were evaluated in an in vitro rumen fermentation using various molecular weights of polyethylene glycols (PEG), polyvinyl pyrrolidone (PVP) and polyvinyl polypyrrolidone as tannin-binding agents. Significant improvement in gas production by addition of PEG4000, 6000 and 20000 and PVP was observed only from black tea by-product, but not from green tea by-product. All tannin binding agents increased $\mathrm{NH}_{3}-\mathrm{N}$ concentration from both green and black tea by-products in the fermentation medium, and the PEG6000 and 20000 showed relatively higher improvement in the $\mathrm{NH}_{3}-\mathrm{N}$ concentration. The PEG6000 and 20000 also improved in vitro organic matter digestibility and metabolizable energy contents of both tea by-products. It was concluded that high molecular PEG would be suitable to assess the suppressive activity of tannins in tea by-products by in vitro fermentation. Higher responses to gas production and $\mathrm{NH}_{3}-\mathrm{N}_{\text {concentration }}$ from black tea by-product than green tea by-product due to PEG indicate that tannins in black tea by-product could suppress rumen fermentation more strongly than that in green tea by-product. (Key Words: Tea By-product, In vitro Rumen Fermentation, Tannin, Tannin Binding Agent)
\end{abstract}

\section{INTRODUCTION}

A large quantity of nitrogen fertilizer has been applied for production of tea leaf rich in amino acids (Oh et al., 2006). Nitrogenous compounds in the leaf are partially extracted by hot water and consumed as tea, but most of the compounds still remain in the residue of tea leaf (Kondo et al., 2004a). As concern increases about environmental issues and material recycling, the utilization of tea byproduct as feedstuff would be useful for both economic and environmental reasons. In Japan, and East Asian and Southeast Asian countries, the consumption of ready-made

\footnotetext{
* Corresponding Author: Makoto Kondo. Tel: +81-59-231-9625, Fax: +81-59-231-9684, E-mail: makok@bio.mie-u.ac.jp

2 Graduate School of Bioagricultural Sciences, Nagoya University, Nagoya 470-0151, Japan.

${ }^{3}$ Tokai Gakuen University, Nagoya 468-0014, Japan.

${ }^{4}$ School of Agriculture, Iwate University, Iwate 020-8550, Japan.

5 Faculty of Animal Science, Bogor Agricultural University, Bogor 16680, Indonesia.

Submitted Mar. 20, 2014; Revised Apr. 26, 2014; Accepted May 12, 2014
}

green and black tea in cans, packs or bottles has increased remarkably in recent years. Beverage companies that manufacture tea drinks produce many tons of tea byproducts annually and most of them are composted. Previous reports showed that tea by-products produced by the beverage industry contained high crude protein $(\mathrm{CP}, 220$ to $350 \mathrm{~g} / \mathrm{kg}$ dry matter; DM) and tannins $(50$ to $80 \mathrm{~g} / \mathrm{kg}$ DM) (Kondo et al., 2004a,b). In order to evaluate the potential use of tea by-products as feedstuffs, the suppressive activity of tea tannins should be assessed.

The suppressive activity of tannins on rumen degradability has been assessed mainly in tropical leguminous leaves and fruit pods (Tolera et al., 1997; Rubanza et al., 2005; Wambui et al., 2012) and agroindustrial by-products (Abarghuei et al., 2010; Al-Masri, 2012; Bhatta et al., 2012). Since polyethylene glycol (PEG) binds tannins and deactivates the anti-nutritive activity, an increase of the in vitro gas production from tannincontaining feeds due to PEG addition means that the tannins lowered the feed degradability in the rumen (Makkar et al., 1995). The higher increment of gas production due to PEG

Copyright $@ 2014$ by Asian-Australasian Journal of Animal Sciences This is an open-access article distributed under the terms of the Creative Commons Attribution Non-Commercial License (http://creativecommons.org/licenses/by-nc/3.0/), which permits unrestricted non-commercial use, distribution, and reproduction in any medium, provided the original work is properly cited. 
administration indicates the higher suppressive activity of tannin in the feeds (Jayanegara et al., 2009). Therefore the in vitro gas production test in conjunction with tanninbinding agents has been used as a useful method for assessing tannin related suppressive activity on ruminant feedstuffs (Rubanza et al., 2005; Osuga et al., 2007). These tannin binding agents can be also useful as dietary supplements when tannin-rich feedstuffs are fed to animals (Ben Salem et al., 1999). However, to date, there has been no information regarding the effects of different molecular weights (MW) of PEG and other tannin binding agents on the in vitro fermentation of tea by-products.

Therefore, the objective of this present study was to assess the anti-nutritive activity of tannins in green and black tea by-products by the in vitro gas production method coupled with ammonia nitrogen $\left(\mathrm{NH}_{3}-\mathrm{N}\right)$ measurement, organic matter (OM) digestibility and metabolizable energy (ME) content. Experiments were conducted to compare the different types of tannin-binding agents on the in vitro test when green or black tea by-products were incubated with buffered rumen fluid.

\section{MATERIALS AND METHODS}

Green and black tea by-products were acquired from a local ready-made tea drink factory. Both green and black tea by-products were freeze-dried and ground to pass through 1 $\mathrm{mm}$ screen. Standard methods as described in AOAC International (2002) were used for determination of DM, $\mathrm{OM}$, and $\mathrm{CP}$. Neutral detergent fiber (NDF), acid detergent fiber (ADF) and acid detergent lignin (ADL) were analyzed as outlined by Van Soest et al. (1991). Acid detergent insoluble protein (ADIP) was determined by the method of Licitra et al. (1996). Total extractable phenolics (TEPH), total extractable tannins (TET), condensed tannins (CT) and protein precipitating capacity (PPC) were determined by the method of Makkar and Goodchild (1996). The PPC was expressed as the amount of bovine serum albumin (BSA) bound with tea by-products. $\mathrm{NH}_{3}-\mathrm{N}$ concentration in the incubated medium was determined using the indophenol reaction (Weatherburn, 1967).

In vitro rumen gas production from tea by-products was determined according to Menke and Steingass (1988). Two hundreds mg of freeze-dried green tea and black tea byproducts passed through $1 \mathrm{~mm}$ screen were weighed each into $100 \mathrm{~mL}$ calibrated glass syringe. Four hundred $\mathrm{mg}$ of various MW of PEG (MW: 1,000, 4,000, 6,000, 20,000), polyvinyl pyrrolidone (PVP, MW: 10,000) or insoluble polyvinyl polypyrrolidone (PVPP) were also added into the syringes. The ratio of feedstuff and PEG, PVP or PVPP were referred to Makkar et al. (1995) and Kondo et al. (2014). The syringes were filled with $30 \mathrm{~mL}$ medium consisting of $10 \mathrm{~mL}$ of rumen fluid and $20 \mathrm{~mL}$ of buffer solution, then incubated in a water bath at $39^{\circ} \mathrm{C}$ in three consecutive runs ( $\mathrm{n}=3$ replicates) and gas production was measured at a series of incubation time for $24 \mathrm{~h}$. The incubated medium was transferred to $50 \mathrm{~mL}$ centrifuge tube and the supernatant collected after centrifuging $(1,090 \times \mathrm{g})$ for $10 \mathrm{~min}$ at $4^{\circ} \mathrm{C}$. $\mathrm{NH}_{3}-\mathrm{N}$ concentration of the supernatant was measured. The data "Increase \%" of gas production or $\mathrm{NH}_{3}-\mathrm{N}$ was calculated as Increase $\%=$ (data with additives - data without additives $\times 100 /$ data without additives. In vitro organic matter digestibility (IVOMD) and ME were estimated from the equation of Makkar (2004) using a gas production data.

The data of gas production, $\mathrm{NH}_{3}-\mathrm{N}$ concentration and estimated IVOMD and ME were analyzed by a factorial analysis of variance, in which the two fixed factors were tea by-products and tannin-binding agents. Rumen content for each incubation batch served as block in the statistical model. When a factor or the interaction showed statistically significant at $\mathrm{p}<0.05$, the differences among treatment means were further tested using Tukey's test. All statistical analyses were performed by using SAS software version 9.3 (SAS Institute, Cary, NC, USA).

\section{RESULTS AND DISCUSSION}

Green and black tea by-products contained $336 \mathrm{CP}$ and 283 g/kg DM, respectively (Table 1). The ADIP content, a lower digestible protein fraction, was relatively higher in black tea by-product than the green one. The NDF, ADF and ADL contents of both tea by-products were similar. The TEPH, including low molecular phenolics and tannins, was present in similar amounts in both tea by-products, approximately $84 \mathrm{~g} / \mathrm{kg}$ DM. The TET content was high in both tea by-products and the values were 76.5 and $66.6 \mathrm{~g} / \mathrm{kg}$ DM in green and black tea by-products, respectively. The

Table 1. Chemical composition of green and black tea byproducts

\begin{tabular}{lcc}
\hline Items & $\begin{array}{c}\text { Green tea } \\
\text { by-product }\end{array}$ & $\begin{array}{c}\text { Black tea } \\
\text { by-product }\end{array}$ \\
\hline Dry matter (DM, g/kg) & 196 & 201 \\
Organic matter (g/kg DM) & 970 & 979 \\
Crude protein (CP, g/kg DM) & 336 & 283 \\
Acid detergent insoluble protein & 70 & 92 \\
$\quad$ (g/kg CP) & & \\
Neutral detergent fiber (g/kg DM) & 388 & 404 \\
Acid detergent fiber (g/kg DM) & 294 & 271 \\
Acid detergent lignin (g/kg DM) & 96.3 & 94.1 \\
Total extractable phenolics (g/kg DM) & 83.4 & 84.8 \\
Total extractable tannins (g/kg DM) & 76.5 & 66.6 \\
Condensed tannins (g/kg DM) & 20.9 & 5.7 \\
Protein precipitating capacity & 18.1 & 65.3 \\
(mg BSA/g DM) & & \\
\hline
\end{tabular}

BSA, bovine serum albumin. 
CT content in green and black tea by-product was 20.9 and $5.7 \mathrm{~g} / \mathrm{kg}$ DM, respectively. The PPC of black tea by-product was more than three times higher than that of green tea. Singh et al. (2005) showed PPC had a high positive correlation with TEPH and CT content in 12 kinds of tropical tree forages. This capacity was not related to the contents of tannins in our study; it is supposed that molecular structures of tannins in tea by-products would be important for their PPC (Yamamoto et al., 1997). Further, tannins have a great structural diversity among various plant sources, and even slight changes in tannin molecular structures could lead to a significant alteration in their biological effects (Mueller-Harvey, 2006).

In vitro gas production from green tea by-product was significantly higher than black tea by-product $(\mathrm{p}<0.05)$ (Table 2), indicating that green tea by-product contained more fermentable substrates. Contrary to expectation, the gas produced from green tea by-product did not increase with the addition of any tannin-binding agents. Significant improvement in gas production by addition of PEG4000, 6000 and 20000 and PVP10000 were observed only in black tea by-product $(\mathrm{p}<0.05)$, but not by PEG1000 and PVPP. The highest increment (18.9\%) in gas production was observed in PEG6000 treatment, but the extent of the increment was not significantly different $(p>0.05)$. Many studies have shown that PEG increased in vitro gas production from most tannin rich feeds (Rubanza et al., 2005; Singh et al., 2005; Osuga et al., 2007). Although green tea by-product contained high tannins, the gas volume did not increase by PEG, PVP or PVPP addition. Apparently tannin biological activity as measured by the capacity of tannins to precipitate protein (BSA) is more related to the increase of gas production as compared to the tannin contents. This is in agreement with Silanikove et al. (2001) who stated that protein precipitation assay is more useful than that of quantification of tannins by colorimetric methods for the evaluation of anti-nutritional effects of the substances. Apart from that, gas production is a result of nutrient fermentation of feed in the rumen, mainly carbohydrate (Menke and Steingass, 1988). It may also indicate that there was no contribution to gas production from fermented substrate in green tea by-product due to supplemental tannin binding agents.

Large differences of response in gas production and $\mathrm{NH}_{3}-\mathrm{N}$ concentration to tannin binding agents were observed in the incubation of green tea by-product (Table 3 ). Contrary to the result of gas production, all kinds of PEG, $\mathrm{PVP}$, and PVPP increased $\mathrm{NH}_{3}-\mathrm{N}$ concentration from green tea by-product. Higher response was obtained in PEG 6000, 20000 and PVPP, but it was not significantly different from other agents. $\mathrm{NH}_{3}-\mathrm{N}$ concentration from black tea byproduct was also increased by addition of any of the agents with the higher response observed with PEG6000, 20000 and PVP10000, while PEG1000 and PVPP showed a relatively lower response. $\mathrm{NH}_{3}$ is the main end-product of protein fermentation in the rumen. The PEG also recovers feed proteins that are bound by tannins. An increased increment of $\mathrm{NH}_{3}-\mathrm{N}$ resulting from the addition of $\mathrm{PEG}$ can be attributed to a reduction in the opportunity of tannin binding to feed protein, which makes tannin-bound protein available to microbial degradation and metabolism (Getachew et al., 2000). The greater increase in $\mathrm{NH}_{3}-\mathrm{N}$ concentration means a greater suppressive effect of tannins on protein degradation. According to the greater $\mathrm{NH}_{3}-\mathrm{N}$ improvement from black tea by-product compared with green by tannin binding agents, protein degradation of black tea by-product would be highly suppressed by its tannins. This result could be reflected in the higher PPC of black tea by-product. The PPC was negatively correlated to $\mathrm{NH}_{3}-\mathrm{N}$ concentration more clearly than gas production because the

Table 2. Effect of addition of polyethylene glycol (PEG), polyvinyl pyrrolidone (PVP) and polyvinyl polypyrrolidone (PVPP) on gas production at $24 \mathrm{~h}$ from green and black tea by-products

\begin{tabular}{|c|c|c|c|c|}
\hline \multirow{2}{*}{ Agents } & \multicolumn{2}{|c|}{ Green tea by-product } & \multicolumn{2}{|c|}{ Black tea by-product } \\
\hline & Gas (mL) & Increase $(\%)$ & Gas (mL) & Increase $(\%)$ \\
\hline Control & 38.9 & & $29.9^{\mathrm{d}}$ & \\
\hline PEG1000* & 38.8 & $-0.1^{\mathrm{a}}$ & $31.3^{\mathrm{bcd}}$ & $4.8^{\mathrm{b}}$ \\
\hline PEG4000 & 38.7 & $-0.4^{\mathrm{a}}$ & $34.0^{\mathrm{ab}}$ & $13.6^{\mathrm{a}}$ \\
\hline PEG6000 & 40.3 & $3.7^{\mathrm{a}}$ & $35.6^{\mathrm{a}}$ & $18.9^{\mathrm{a}}$ \\
\hline PEG20000 & 40.2 & $3.5^{\mathrm{a}}$ & $34.6^{\mathrm{a}}$ & $15.7^{\mathrm{a}}$ \\
\hline PVP10000 & 38.3 & $-1.4^{\mathrm{ab}}$ & $33.4^{\mathrm{abc}}$ & $11.7^{\mathrm{ab}}$ \\
\hline PVPP & 36.0 & $-7.4^{\mathrm{b}}$ & $31.2^{\mathrm{cd}}$ & $4.4^{\mathrm{b}}$ \\
\hline SEM & 1.09 & 1.42 & 0.56 & 1.75 \\
\hline \multicolumn{5}{|l|}{ p-value } \\
\hline Tea by-products & $<0.001$ & $<0.001$ & & \\
\hline Tannin binding agents & $<0.001$ & $<0.001$ & & \\
\hline Interaction & 0.110 & 0.053 & & \\
\hline
\end{tabular}

SEM, standard error of the mean. * Molecular weight.

${ }^{\text {abcd }}$ Means with different letters within a column are significantly different $(\mathrm{p}<0.05)$. 
Table 3. Effect of addition of polyethylene glycol (PEG), polyvinyl pyrrolidone (PVP) and polyvinyl polypyrrolidone (PVPP) on ammonia nitrogen $\left(\mathrm{NH}_{3}-\mathrm{N}\right)$ at $24 \mathrm{~h}$ from green and black tea by-products

\begin{tabular}{|c|c|c|c|c|}
\hline \multirow{2}{*}{ Agents } & \multicolumn{2}{|c|}{ Green tea by-product } & \multicolumn{2}{|c|}{ Black tea by-product } \\
\hline & $\mathrm{NH}_{3}-\mathrm{N}(\mathrm{mg} / \mathrm{dL})$ & Increase $(\%)$ & $\mathrm{NH}_{3}-\mathrm{N}(\mathrm{mg} / \mathrm{dL})$ & Increase $(\%)$ \\
\hline Control & $25.2^{\mathrm{b}}$ & & $16.9^{c}$ & \\
\hline PEG1000* & $29.0^{\mathrm{a}}$ & 15.1 & $18.3^{\mathrm{bc}}$ & $8.4^{\mathrm{b}}$ \\
\hline PEG4000 & $28.7^{\mathrm{a}}$ & 13.8 & $21.7^{\mathrm{a}}$ & $28.5^{\mathrm{a}}$ \\
\hline PEG6000 & $29.5^{\mathrm{a}}$ & 17.0 & $22.5^{\mathrm{a}}$ & $33.2^{\mathrm{a}}$ \\
\hline PEG20000 & $29.3^{\mathrm{a}}$ & 16.4 & $22.6^{\mathrm{a}}$ & $33.7^{\mathrm{a}}$ \\
\hline PVP10000 & $29.0^{\mathrm{a}}$ & 15.2 & $22.5^{\mathrm{a}}$ & $33.5^{\mathrm{a}}$ \\
\hline PVPP & $29.7^{\mathrm{a}}$ & 18.0 & $19.6^{\mathrm{b}}$ & $15.9^{\mathrm{b}}$ \\
\hline SEM & 0.62 & 2.60 & 0.38 & 2.28 \\
\hline \multicolumn{5}{|l|}{$\mathrm{p}$-value } \\
\hline Tea by-products & $<0.001$ & $<0.001$ & & \\
\hline Tannin binding agents & 0.011 & $<0.001$ & & \\
\hline Interaction & $<0.001$ & $<0.001$ & & \\
\hline
\end{tabular}

SEM, standard error of the mean. * Molecular weight.

${ }^{a b c}$ Means with different letters within a column are significantly different $(\mathrm{p}<0.05)$.

increase ratio to $\mathrm{NH}_{3}-\mathrm{N}$ concentration by tannin binding agents was relatively higher than that to the gas production. Although in vitro rumen gas test with tannin-binding agents has been well-accepted method to identify anti-nutritional activity of tannin for rumen fermentation (Tolera et al., 1997; Rubanza et al., 2005; Osuga et al., 2007), measurement of gas production cannot fully assess the effects of tannin on feed degradation according to the response of PEG, PVP, and PVPP to green tea by-product. Additional to measurement of gas production, monitoring $\mathrm{NH}_{3}-\mathrm{N}$ concentration in the incubated medium is recommended for tannin bioassay by in vitro rumen gas test. According to the present data, PEG6000 and 20000 would be suitable to assess the suppressive activity of tea tannins on protein degradability in the rumen. Makkar et al. (1995) supports this observation as they also reported that
PEG6000 and PEG10000 showed relatively higher improvements by the gas production test from tannin-rich feeds. This could be due the binding of PEG and phenols takes place via $\mathrm{H}$ bonding, therefore, highly polymerized PEG contains more effective sites (oxygen of ether linkage) which bind to the hydroxyl group of tannins (Jones, 1965). PEG1000 and PVPP were less effective on gas production and $\mathrm{NH}_{3}-\mathrm{N}$ concentration from black tea by-product. These results indicate that the low MW $(\sim 1,000)$ of PEG and insoluble PVPP would be least effective on binding to black tea tannin.

The estimated IVOMD and ME content were higher in green by-product than in black tea (Tables 4 and 5), and these values were comparable or higher than several ruminant browse forages containing tannin (Rubanza et al, 2005; Osuga et al., 2006;2007). None of the tannin binding

Table 4. Effect of addition of polyethylene glycol (PEG), polyvinyl pyrrolidone (PVP) and polyvinyl polypyrrolidone (PVPP) on estimated in vitro organic matter digestibility (IVOMD) at $24 \mathrm{~h}$ from green and black tea by-products

\begin{tabular}{|c|c|c|c|c|}
\hline \multirow{2}{*}{ Agents } & \multicolumn{2}{|c|}{ Green tea by-product } & \multicolumn{2}{|c|}{ Black tea by-product } \\
\hline & IVOMD (\%) & Increase $(\%)$ & IVOMD (\%) & Increase $(\%)$ \\
\hline Control & 64.8 & & $54.3^{\mathrm{c}}$ & \\
\hline PEG1000* & 64.7 & $0.0^{\mathrm{a}}$ & $55.6^{\mathrm{bcd}}$ & $2.4^{\mathrm{b}}$ \\
\hline PEG4000 & 64.6 & $-0.2^{\mathrm{a}}$ & $57.9^{\mathrm{ab}}$ & $6.7^{\mathrm{a}}$ \\
\hline PEG6000 & 66.0 & $2.0^{\mathrm{a}}$ & $59.4^{\mathrm{a}}$ & $9.3^{\mathrm{a}}$ \\
\hline PEG20000 & 66.0 & $1.9^{\mathrm{a}}$ & $58.5^{\mathrm{a}}$ & $7.7^{\mathrm{a}}$ \\
\hline PVP10000 & 64.3 & $-0.7^{\mathrm{ab}}$ & $57.4^{\mathrm{abc}}$ & $5.7^{\mathrm{ab}}$ \\
\hline PVPP & 62.2 & $-4.0^{\mathrm{b}}$ & $55.5^{\mathrm{cd}}$ & $2.1^{\mathrm{b}}$ \\
\hline SEM & 0.96 & 0.76 & 0.49 & 0.86 \\
\hline \multicolumn{5}{|l|}{$\mathrm{p}$-value } \\
\hline Tea by-products & $<0.001$ & $<0.001$ & & \\
\hline Tannin binding agents & $<0.001$ & $<0.001$ & & \\
\hline Interaction & 0.107 & 0.072 & & \\
\hline
\end{tabular}

DM, dry matter; SEM, standard error of the mean. * Molecular weight.

${ }^{\text {abcd }}$ Means with different letters within a column are significantly different $(\mathrm{p}<0.05)$. 
Table 5. Effect of addition of polyethylene glycol (PEG), polyvinyl pyrrolidone (PVP) and polyvinyl polypyrrolidone (PVPP) on estimated metabolizable energy (ME) of green and black tea by-products

\begin{tabular}{lcccc}
\hline \multirow{2}{*}{ Agents } & \multicolumn{2}{c}{ Green tea by-product } & & \multicolumn{2}{c}{ Black tea by-product } \\
\cline { 2 - 3 } \cline { 5 - 5 } Control & ME $(\mathrm{MJ} / \mathrm{kg} \mathrm{DM})$ & Increase $(\%)$ & ME $(\mathrm{MJ} / \mathrm{kg} \mathrm{DM})$ & Increase $(\%)$ \\
PEG1000* & 9.40 & & $7.88^{\mathrm{d}}$ & $2.5^{\mathrm{b}}$ \\
PEG4000 & 9.40 & $0.0^{\mathrm{a}}$ & $8.08^{\mathrm{bcd}}$ & $7.0^{\mathrm{a}}$ \\
PEG6000 & 9.38 & $-0.2^{\mathrm{a}}$ & $8.43^{\mathrm{ab}}$ & $9.8^{\mathrm{a}}$ \\
PEG20000 & 9.60 & $2.1^{\mathrm{a}}$ & $8.65^{\mathrm{a}}$ & $8.1^{\mathrm{a}}$ \\
PVP10000 & 9.59 & $2.0^{\mathrm{a}}$ & $8.52^{\mathrm{a}}$ & $6.0^{\mathrm{ab}}$ \\
PVPP & 9.33 & $-0.8^{\mathrm{ab}}$ & $8.36^{\mathrm{abc}}$ & $2.3^{\mathrm{b}}$ \\
SEM & 9.01 & $-4.2^{\mathrm{b}}$ & $8.06^{\mathrm{cd}}$ & 0.89 \\
p-value & 0.14 & 0.78 & 0.08 & \\
Tea by-products & & & & \\
Tannin binding agents & $<0.001$ & $<0.001$ & & \\
Interaction & $<0.001$ & $<0.001$ & &
\end{tabular}

DM, dry matter; SEM, standard error of the mean. * Molecular weight.

${ }^{\text {abcd }}$ Means with different letters within a column are significantly different $(\mathrm{p}<0.05)$.

agents affected IVOMD and ME content of green tea byproduct, but PEG4000, 6000, and 20000 significantly increased IVOMD and ME content of black tea by-products $(\mathrm{p}<0.05)$. These parameters of both tea by-products were numerically high when PEG6000 and 20000 were used; indicating that highly polymerized PEG can improve nutritional value of tea by-product.

Min et al. (2003) reviewed that lower CT contents (20 to $45 \mathrm{~g} / \mathrm{kg} \mathrm{DM}$ ) in temperate legumes improve nitrogen utilization, and milk and wool production in ruminants; in contrast, higher CT contents $(>50 \mathrm{~g} / \mathrm{kg}$ DM) reduce voluntary feed intake and digestibility, and depress rates of body and wool growth. Compared to these studies, CT content in both tea by-products were low; however, the in vitro fermentation was suppressed by their tannins. These different observations could be due to the effects produced are not the same for all $\mathrm{CT}$, but rather depend upon the concentration, molecular structure, and biological activity of the CT (Min et al., 2003; Waghorn, 2008). It can also be expected that phenolic compounds other than CT present in green and black tea by-products could possess PPC and therefore may suppress the in vitro fermentation, such as epigallocatechin-3-gallate, epicatechin-3-gallate in green tea, and the aflavins in black tea (Yang et al., 2000). In the present study, despite of lower CT in the black tea byproduct than that in green, PPC and increment of in vitro fermentation with PEG in black tea by-product were higher than those in green one. These findings suggest that CT measured by colorimetric assay for tea by-products might not be related to tannin's biological activity.

\section{CONCLUSION}

The present study confirms the potentiality of green and black tea by-products to be used as protein-rich feedstuffs as indicated by their high $\mathrm{CP}$ contents. However, the concomitantly high tannin contents in the by-products may limit their utilization by ruminant livestock. Addition of tannin binding agents, especially PEG with higher MW $(6,000$ and 2,0000), is apparently suitable to deactivate the suppressive activity of the tannins as shown by the elevated values of total gas production, $\mathrm{NH}_{3}-\mathrm{N}$ concentration, IVOMD and ME contents in vitro in comparison with the control groups. Between the two tea by-products, greater responses in gas production and $\mathrm{NH}_{3}-\mathrm{N}$ concentration from the black tea by-product than from the green tea by-product due to PEG addition indicate that tannins in black tea byproduct could suppress rumen fermentation more strongly than that in green tea by-product. Such responses seem to be more correlated with the PPC properties rather than the concentrations of tannins (either TET or CT) in the byproducts. Thus, tannin bioassay (like the PPC) is apparently better for predicting nutrient utilization in the rumen than the colorimetric assay. Further studies are required for assessment of the nutritional values of these tea by-products as protein supplements with PEG addition in in vivo animal feeding experiments.

\section{REFERENCES}

Abarghuei, M. J., Y. Rouzbehan, and D. Alipour. 2010. The influence of the grape pomace on the ruminal parameters of sheep. Livest. Sci. 132:73-79.

Al-Masri, M. R. 2012. An in vitro nutritive evaluation of olive tree (Olea europaea) pruning residues as affected by cutting regimen. Bioresour. Technol. 103:234-238.

AOAC International. 2002. Official Methods of Analysis of AOAC International. 17th ed., Gaithersburg, MD, USA.

Ben Salem, H., A. Nefzaoui, L. Ben Salem, and J. L. Tisserand. 
1999. Different means of administering polyethylene glycol to sheep: effect on the nutritive value of Acacia cyanophylla Lindl. foliage. Anim. Sci. 68:809-818.

Bhatta, R., S. Mani, L. Saruah, and K. T. Sampath. 2012. Phenolic composition, fermentation profile, protozoa population and methane production from sheanut (Butryospermum Parkii) byproducts in vitro. Asian Australas. J. Anim. Sci. 25:13891394.

Getachew, G., H. P. S. Makkar, and K. Becker. 2000. Effect of polyethylene glycol on in vitro degradability of nitrogen and microbial protein synthesis from tannin-rich browse and herbaceous legumes. Br. J. Nutr. 84:73-83.

Jayanegara, A., N. Togtokhbayar, H. P. S. Makkar, and K. Becker. 2009. Tannins determined by various methods as predictors of methane production reduction potential of plants by an in vitro rumen fermentation system. Anim. Feed Sci. Technol. 150:230-237.

Jones, D. E. 1965. Banana tannin and its reaction with polyethylene glycols. Nature 206:299-300.

Kondo, M., K. Kita, and H. Yokota. 2004a. Effects of tea leaf waste of green tea, oolong tea, and black tea addition on Sudangrass silage quality and in vitro gas production. J. Sci. Food Agric. 84:721-727.

Kondo, M., N. Nishino, K. Kita, and H. Yokota. 2004b. Enhanced lactic acid fermentation of silage by the addition of green tea waste. J. Sci. Food Agric. 84: 728-734.

Kondo, M., Y. Hirano, K. Kita, A. Jayanegara, and H. Yokota. 2014. Fermentation characteristics, tannin contents and in vitro ruminal degradation of green tea and black tea by-products ensiled at different temperatures. Asian Australas. J. Anim. Sci. 27:937-945.

Licitra, G., T. M. Hernandez, and P. J. Van Soest. 1996. Standarization of procedures for nitrogen fractionation of ruminant feed. Anim. Feed Sci. Technol. 57:347-358.

Makkar, H. P. S. 2004. Recent advances in the in vitro gas method for evaluation of nutritional quality of feed resources, in: Assessing quality and safety of animal feeds. FAO Animal Production and Health 160, Rome, Italy. pp. 55-88.

Makkar, H. P. S., M. Blummel, and K. Becker. 1995. Formation of complexes between polyvinyl pyrrolidones or polyethylene glycols and tannins, and their implication in gas production and true digestibility in in vitro techniques. Br. J. Nutr. 73: 897-913.

Makkar, H. P. S. and A. V. Goodchild. 1996. Quantification of tannins: a laboratory manual. ICARDA, Aleppo, Syria.
Menke, K. H. and H. Stengass. 1988. Estimation of the energetic feed value obtained from chemical analysis and in vitro gas production using rumen fluid. Anim. Res. Dev. 28:7-55.

Mueller-Harvey, I. 2006. Unravelling the conundrum of tannins in animal nutrition and health. J. Sci. Food Agric. 86:2010-2037.

Oh, K., T. Kato, Z. P. Li, and F. Y. Li. 2006. Environmental problems from tea cultivation in Japan and a control measure using calcium cyanamide. Pedosphere 16:770-777.

Osuga, I. M., S. A. Abdulrazak, T. Ichinohe, J. O. Ondiek, and T. Fujihara. 2006. Degradation characteristics and tannin bioassay of some browse forage from Kenya harvested during the dry season. Anim. Sci. J. 77:414-421.

Osuga, I. M., C. N. Maindi, S. A. Abdlurazak, N. Nishino, T. Ichinohe, and T. Fujihara. 2007. Potential nutritive value and tannin bioassay of selected Acacia species from Kenya. J. Sci. Food Agric. 87:1533-1538.

Rubanza, C. D. K., M. N. Shem, R. Otsyina, S. S. Bakengesa, T. Ichinohe, and T. Fujihara, T. 2005. Polyphenolics and tannins effect on in vitro digestibility of selected Acacia species leaves. Anim. Feed Sci. Technol. 119:129-142.

Silanikove, N., A. Perevolotsky, and F. D. Provenza. 2001. Use of tannin-binding chemicals to assay for tannins and their negative postingestive effects in ruminants. Anim. Feed Sci. Technol. 91:69-81.

Singh, B., A. Sahoo, R. Sharma, and T. K. Bhat. 2005. Effect of polyethylene glycol on gas production parameters and nitrogen disappearance of some tree forages. Anim. Feed Sci. Technol. 123:351-364.

Tolera, A., K. Khazaal, and E. R. Ørskov. 1997. Nutritive evaluation of some browse species. Anim. Feed Sci. Technol. 67:181-195.

Van Soest, P. J., J. D. Robertson, and B. A. Lewis. 1991. Methods for dietary fiber, Neutral detergent fiber, and nonstarch polysaccharides in relation to animal nutrition. J. Dairy Sci. 74:3583-3597.

Wambui, C. C., S. Ando, S. A. Abdulrazak, I. M. Osuga, and T. Ichinohe. 2012. In vitro assessment of ruminal fermentation characteristics of tropical browse mixtures supplemented with yeast. Grassl. Sci. 58:53-57.

Weatherburn, M. W. 1967. Phenol-hypochlorite reaction for determination of ammonia. Anal. Chem. 39:971-974.

Yamamoto, T., L. R. Juneja, D. C. Chu, and M. Kim. 1997. Chemistry and Applications of Green Tea. CRC press, Florida, USA.

Yang, C. S. and J. M. Landau. 2000. Effects of tea consumption on nutrition and health. J. Nutr. 130:2409-2412. 